University of Louisville

ThinkIR: The University of Louisville's Institutional Repository

\title{
$5-2015$
}

\section{Correlation between crime and vegetation : a case study of Jefferson County, Kentucky.}

\author{
Yi Ling Chan \\ University of Louisville
}

Follow this and additional works at: https://ir.library.louisville.edu/honors

Part of the Physical Sciences and Mathematics Commons

\section{Recommended Citation}

Chan, Yi Ling, "Correlation between crime and vegetation : a case study of Jefferson County, Kentucky." (2015). College of Arts \& Sciences Senior Honors Theses. Paper 67.

http://doi.org/10.18297/honors/67

This Senior Honors Thesis is brought to you for free and open access by the College of Arts \& Sciences at ThinkIR: The University of Louisville's Institutional Repository. It has been accepted for inclusion in College of Arts \& Sciences Senior Honors Theses by an authorized administrator of ThinkIR: The University of Louisville's Institutional Repository. This title appears here courtesy of the author, who has retained all other copyrights. For more information, please contact thinkir@louisville.edu. 


\title{
Correlation Between Crime and Vegetation: A Case Study of Jefferson County, Kentucky
}

\author{
By \\ Yi Ling Chan \\ Submitted in partial fulfillment of the requirements \\ for Graduation magna cum laude \\ and \\ for Graduation with Honors \\ from the Department of Geography and Geosciences \\ University of Louisville \\ May 2015
}




\section{Table Of Contents}

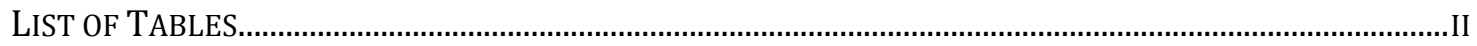

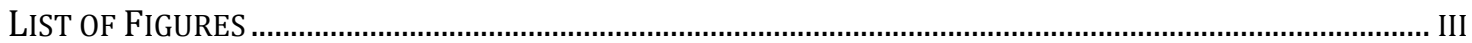

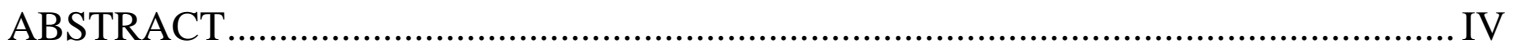

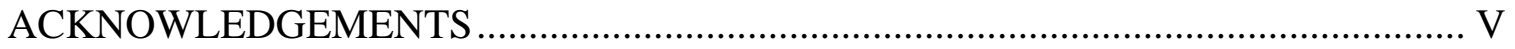



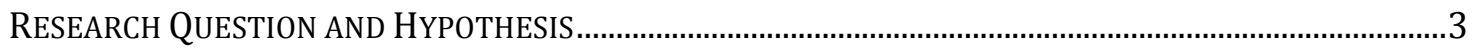



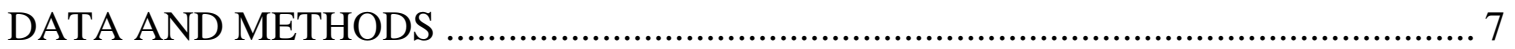

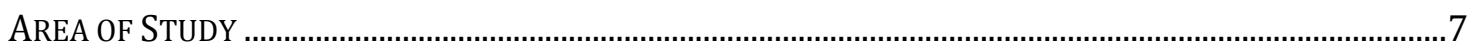



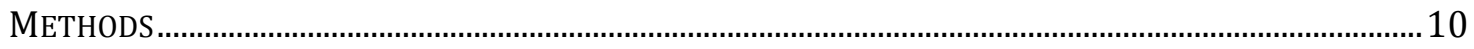

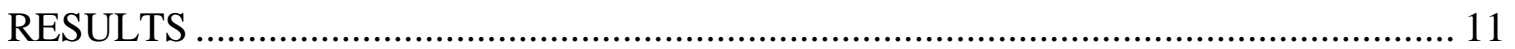






\section{List of Tables}

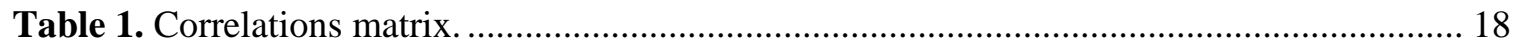






\section{List of Figures}

Figure 1. Study area: Jefferson County, Kentucky. Data: LOJIC (2011) .................................. 7



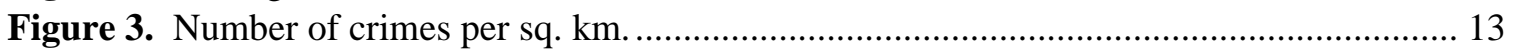

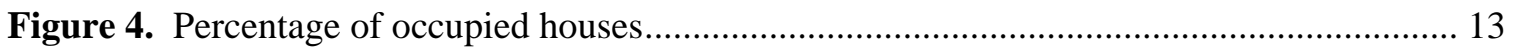

Figure 5. Percentage of people in each block group living in poverty..................................... 14

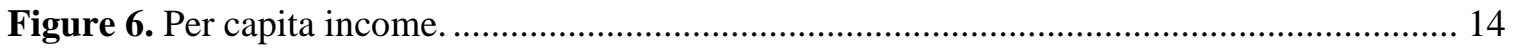

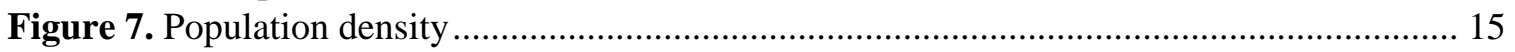

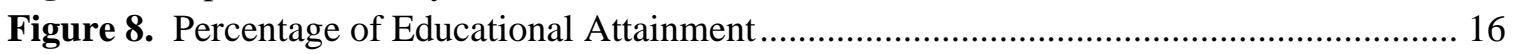

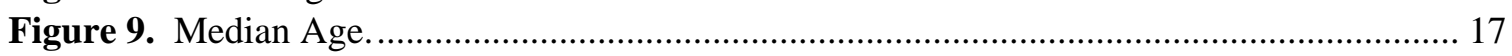

Figure 10. Percentage of houses that are owned/mortgaged. ................................................. 17

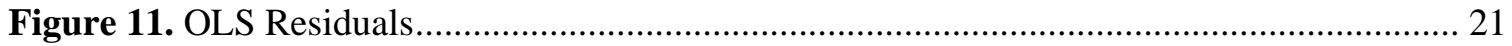




\section{ABSTRACT}

Conflicting evidence exists about environmental determinants of crime. While scholars agree there is a relationship between environmental factors and crime, there is not consistency among measures of associations. Looking specifically at the influence of vegetation, there is disagreement as to whether vegetation promotes or deters crime. Some studies show criminals use vegetation as a tool to conceal themselves, while others show vegetation serves as a territory marker, which discourages criminals. My research explores these factors within Jefferson County, Kentucky’s largest and most urban, using NDVI as a proxy for vegetation cover and spatially explicit crime densities aggregated to the census block group level. Of over 30 types of crime, I subset crimes to those that tend to occur outdoors: assault, auto theft, burglary, robbery, and theft. Percent of occupied houses, percent owned/mortgaged houses, median age, per capita income, educational attainment, population density and percent in poverty were considered as potentially cofounding aspects of this relationship. The explanatory power of vegetation in regards to crime density was tested using multivariate ordinary least squares regression. The study found that even after accounting for other socioeconomic factors, crime and vegetation have a statistically significant negative relationship. This research provides evidence in exploring the influence of vegetation on crime and, combined with ongoing research into criminal motivations, provides insight into how vegetation conditions might better be included in managing crime in urban areas. 


\section{ACKNOWLEDGEMENTS}

I am very grateful for my mentor, Dr. Wei Song, and my second reader, Dr. Forrest Stevens for their generous support with my thesis. I would like to thank Dr. Song for being instrumental in this research project by keeping me on track, helping with my research, giving advice, and in providing supplemental information. I would also like to thank Dr. Stevens for his help in guiding me through my research and providing me with beneficial revisions and recommendations. 


\section{INTRODUCTION}

Some scholars have suggested that there is a correlation between crime and amounts of vegetation in a region; however, this relationship has not been explored within Jefferson County, Kentucky. Crime Prevention Through Environmental Design (CPTED) is a field devoted to strategically managing the environment to reduce crime (Wortley and Mazerolle 2013). Through the process of recognizing aspects of the physical environment that are related with crime, we can modify these features to discourage crimes from occurring in the future (Jeffrey 1971). One aspect of this pertains to amounts of vegetation in an area and its relationship to crime. My thesis seeks to explore this relationship between crime and vegetation in Jefferson County.

There is not strong agreement on the relationship between urban crime and vegetation. Some scholars believe that areas with more vegetation, especially vegetation that is dense and low-lying, such as shrubs or bushes, encourage crime because this provides concealment to perpetrators (Fisher and Nasar 1992). This supports the view that vegetation should be removed from areas to decrease crime. Some citizens are even fearful of areas with vegetation. A study that asked participants their opinion of 26 different landscape photographs showed that they preferred well-maintained areas and were fearful of dense woody vegetation (Talbot and Kaplan 1984).

However, not all vegetation reduces visibility. In fact, recent research has shown that there tends to be fewer crimes in areas that have a larger abundance of vegetation. A study using geocoded crime data along with high resolution tree canopy data explored this issue in Baltimore and found that every 10 percent increase in canopy cover was 
associated with an approximately 12 percent decrease in crime (Troy, Grove, and O’NeilDunne 2012). This study also found that the associations between crime and tree canopy were larger on public land than on private land. This indicates that different types of land use are connected with human interactions and relationships with vegetation. Other studies have also indicated that crime and vegetation are inversely related. A study in Philadelphia found that more vegetation is associated with lower rates of assaults, robberies, and burglaries (Wolfe and Mennis 2012).

Routine activities theory, established by Felson and Cohen (1979), argues that for a crime to happen there must be a convergence of a motivated offender, a suitable target, and the absence of capable guardians. The role of the environment plays a large part in the third component of this theory. People are more inclined to be in public areas that have more vegetation, as these areas are more appealing (Troy, Grove, and O’Neil-Dunne 2012). Therefore, with more people present, there are more watchful eyes that can act as guardians to deter crime (Kuo and Sullivan 2001a).

A component of CPTED, broken windows theory argues that criminals are more attracted to neighborhoods and areas that seem poorly maintained (Kelling and Wilson 1982). This theory indicates that once communal barriers are lessened to signify no one cares, vandalism and crime can happen anywhere. If features of a residence or property indicate that the owner does not care for it, then people are more likely to commit crimes on the property than if it was in pristine condition. If a window is broken and left unfixed, it signifies that the building is not important enough for the owners to fix it and soon all of the windows of the building will be broken. Similarly, an area lacking 
vegetation leaves places appearing poorly maintained, suggesting to criminals that they are better off committing crimes there.

Furthermore, vegetation reduces psychological precursors to violence, such as mental fatigue (Kuo and Sullivan 2001a). Mental fatigue can contribute to aggression via affecting cognitive processing, emotions, and behavior (Kuo and Sullivan 2001b). A study was conducted of 142 residents of urban public housing who were randomly assigned to buildings, each with different levels of vegetation. It revealed that levels of aggression were higher in residents living in more barren buildings (Kuo and Sullivan 2001b). Since aggression is related to crime, barren buildings are often associated with higher levels of crime, while more vegetated areas may have lower levels of crime.

\section{Research Question and Hypothesis}

This thesis answers the question, "What relationship exists between crime density and amounts of vegetation in Jefferson County, Kentucky?” I hypothesized that areas with less vegetation will have higher densities of crime, while the areas with more vegetation will have lower crime densities. This thesis seeks to investigate if there is a significant correlation between crime density and measures of vegetation in Jefferson County when controlling for potentially cofounding demographic and socioeconomic factors. Understanding this relationship has great implications for Louisville and crime prevention through analysis of more effective policing and urban planning efforts. With the impending threats of climate change, many cities share a goal of reducing negative impacts on the environment, which may also impact crime. This can be achieved in part through planting more florae throughout the city. The city of Louisville has its own Tree Advisory Commission as a measure to involve the community in green activities 
(Louisville Metro Government 2014). Using the results of this study can guide the city to plant trees in ways that are both sustainable and crime preventative. Furthermore, this study adds to research that investigates the association between crime and vegetation by providing another case study in an important southern city.

\section{LITERATURE REVIEW}

Crime is a large cost to individuals and societies, and it has even been argued that crime can be considered a form of pollution to communities (Glasson and Cozens 2011). Environmental criminology was born in the $19^{\text {th }}$ century, as those living in the period of industrialization began to notice connections between their built environments and crime (Maguire, Morgan, and Reiner 2002, 620). This branch of criminology is focused on explaining spatial distributions of offences and of the offender (Maguire, Morgan, and Reiner 2002, 620).

Prospect refuge theory, an aspect of environmental criminology, states that people prefer areas that allow them to see their surroundings, while also being able to seek refuge in their environment (Fisher and Nasar 1992). Areas with low-lying shrubs and open grassland allow for this type of prospect and refuge. Prospect refuge theory applies to everyone, including criminals. A study of automobile burglaries was conducted in Washington DC (Michael, Hull, and Zahm 2001). It was found that vegetated areas, such as parks, offer concealment. Furthermore, burglars use the features of an area to reduce their risk of getting caught. Supporting prospect refuge theory, Fisher and Nasar (1992) found that people fear crime the most when areas provide protection for potential offenders, but little possibility for escape to potential victims. 
Another component of environmental criminology is routine activities theory, which focuses on the circumstances in which the crime was carried out, instead of the offender (Cohen and Felson 1979). According to this theory, the absence of capable guardians is one of the key drivers for a crime to take place. However, more vegetation in an area tends to result in increased use by residents of their outdoor spaces (Kuo and Sullivan 2001a). Residents of a neighborhood that spend time outdoors thus become capable guardians, deterring potential acts of crime in the area.

Donovan and Prestemon (2012) used routine activities theory and broken windows theory to assess the relationship between tree cover and crime in a precinct of Portland, Oregon. The authors collected crime data and made site visits to each of the 2,813 single-family homes that were a part of the study. Variables considered in the study included level of window protection, barriers to the property, alarm systems, neighborhood watches, porches, street lighting, number of trees, size of trees, and attributes of the house. These elements may influence the motivation of the potential criminal, as they allow the perpetrator to weigh the potential costs versus potential benefits. The authors found the strongest negative relationship between tree cover and crime where trees were in the public right of way.

Other studies have also analyzed the relationship between crime and vegetation. Kuo and Sullivan (2011a) analyzed the crime rates of 98 apartments within a public housing development in Chicago, Illinois. Buildings had varying levels of vegetation, however most of the residents had very similar incomes, levels of education, and life circumstances, allowing for a unique level of homogeneity. The authors of the study used Chicago Police Department crime reports and vegetation data extracted from many 
slide photographs of the public housing area from a helicopter. Multivariate ordinary least squares regression (OLS) was conducted, indicating that there was a statistically significant negative relationship between the two variables. In the areas with high vegetation, there were roughly 50 percent fewer crimes than areas with lower vegetation. When the authors considered all the predictors of crime together, they found that vegetation was still able to make a unique contribution to the results (Kuo and Sullivan 2011a).

Several studies similar to this thesis have been conducted. An analysis in Baltimore summarized a crime index consisting of crimes including combined robbery, burglary, theft, and shooting and a tree canopy layer into census block groups. An OLS regression was performed using the crime index as the dependent variable and amount of tree canopy cover by block group as the independent variable, along with several other socioeconomic factors. This study found that there was a 20 percent decrease in crime for every 10 percent increase in tree canopy. Furthermore, the relationship between crime and vegetation was 40 percent stronger on public land than on private land. The authors concluded that planting trees on public land would have better benefits in crime reduction than planting trees on private land (Troy, Grove, and O'Neil-Dunne 2012). In a similar study of Philadelphia, Pennsylvania using levels of vegetation derived from a calculated NDVI and crime data points aggregated into census tracts, the authors found that more vegetation was associated with lower levels of assault, robbery, and burglary, but not theft (Wolfe and Mennis 2012). 


\section{DATA AND METHODS}

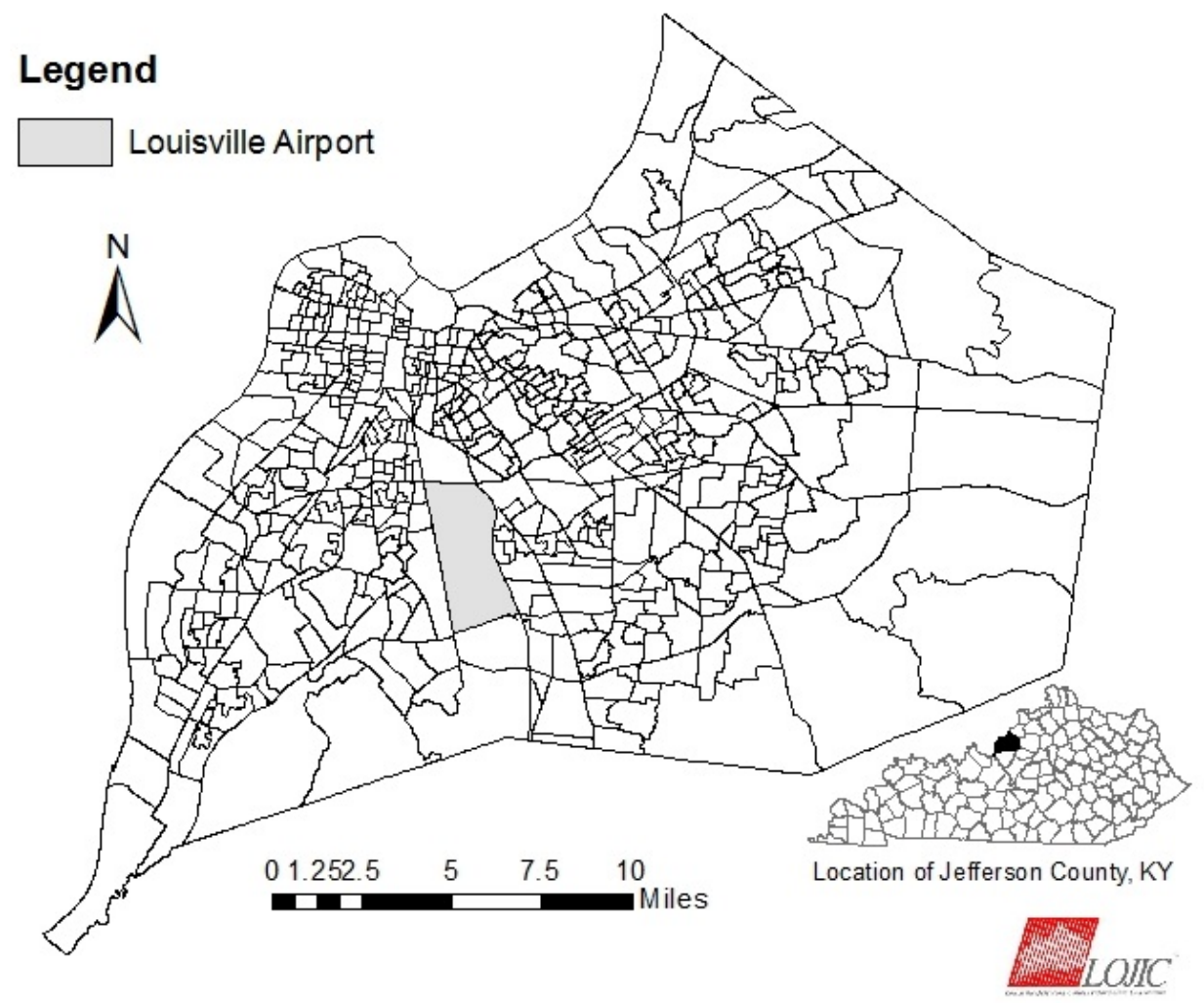

Figure 1. Study area: Jefferson County, Kentucky. Data: LOJIC (2011).

\section{Area of Study}

The focus of this study was Jefferson County, Kentucky, which merged with the city of Louisville in 2003 (Figure 1). This is the largest county in Kentucky, with population in 2010 of 741,096 people (US Census Bureau 2010a). Furthermore the county is approximately 98.6 percent urban, making it a good area for the study of urban crimes (US Census Bureau 2010b).

\section{Data}

The two main groups of data necessary for this study are crime data and vegetation data within Jefferson County. The Department of Justice Administration at 
the University of Louisville provided crime data from the Louisville Metro Police Department spanning from 2009-2012. These data contained around 30 different types of crime. Of these, assault, auto theft, burglary, robbery, and theft crimes were considered, since these events tend to occur outdoors, or could more likely be influenced by environmental factors, such as added concealment or “eyes on the street” (Jacobs 1961). The crime data included the date, time of crime, case number, and address of crime. It did not, however, include any names of perpetrators or victims. Crime data were aggregated into census block groups. To measure the relative crime risk, the crime data were then converted into the crime density for each block group. This was calculated as a ratio of number of crimes to the total square kilometers of each block group.

Census block groups of Jefferson County were the basic unit of spatial analysis. This is the smallest possible unit of spatial analysis that also contains data on socioeconomic factors of the area. In Jefferson County there are 575 block groups, with the smallest block group at 0.038 square miles and the largest totaling 14.54 square miles. However, on average the block groups are only 0.7 square miles. One of the larger block groups is the area surrounding the Louisville International Airport. This area was excluded from the study, as it is an outlier that is fairly large (6.78 square miles) relative to the other census block groups, and more importantly, is a commercial area in which only five people live.

Socioeconomic factors hypothesized to be associated with crimes were percent owned/mortgaged houses, percent occupied houses, population density, median age, per capita income, percent educational attainment, and percent of residents in poverty. All data were collected at the block group level. Number of owned/mortgaged houses, 
occupied houses, population density and median age were collected from the 2010 Census Data. Per capita income, educational attainment, and poverty data were gathered from the 2009-2013 American Community Survey 5-Year estimate.

Educational attainment was defined as the amount of the population over 25 that has received at least a high school diploma or equivalent. Population density was calculated as the total population within the block group per square kilometer. Percent in poverty was defined as a ratio of the number of households living under the poverty level to the total householders per block group. Per capita income was collected using 2013 inflation-adjusted dollars.

These potential covariates were chosen because many of them have shown to be statistically associated with crime. Furthermore, some of them were chosen through the application of a combination of theories already mentioned. As routine activities theory states, there must be a lack of capable guardians in an area for a crime to happen. Therefore, it is probable that the amount of occupied houses, owned or mortgaged houses, and median age are strongly associated with crime. Less occupied houses will signify to potential perpetrators that there will not be consequences for committing crimes in or around the area. Additionally, areas with fewer owned homes and higher concentrations of young people may contain larger populations of those with a lessened sense of ownership of the area, and they are not as likely to act as capable guardians against crime. Broken windows theory supports income as a possible covariate, as people with lower incomes are less likely to be able to afford to maintain their homes. This in turn may signify to potential criminals that there is less sense of ownership, and therefore they are likely to get away with committing crime in the area. 
Vegetation data was collected via remote sensing methods. Using a Landsat image of Jefferson County from September 2014, Normalized Difference Vegetation Index (NDVI) values were calculated for each pixel of the satellite image, using equation 1.

$$
N D V I=\frac{\rho_{860 \mathrm{~nm}}-\rho_{660 \mathrm{~nm}}}{\rho_{860 \mathrm{~nm}}+\rho_{660 \mathrm{~nm}}}
$$

NDVI is a ratio of near infrared spectral reflectance measurement $\left(\rho_{860 \mathrm{~nm}}\right)$ and the visible red spectral reflectance measurements $\left(\rho_{660 \mathrm{~nm}}\right)$ (Jensen 2005). The NDVI values

range from -1 to 1 , where higher levels of green, photosynthesizing vegetation are usually closer to 1 . Low values, (below 0.1) tend to correspond to barren areas; moderate values (between 0.2 to 0.3 ) may correspond to shrubs and grasslands; high values (0.6 to 0.8 ) indicate healthy, green and active photosynthesizing vegetation (NASA Earth Observatory 2000). As the Ohio River and other significant bodies of water were likely to influence the mean NDVI value of many census block groups, all bodies of water were masked from the raster file by using the LANDFIRE land cover classification and the raster calculator within ArcMap (ESRI 2011). Average NDVI values at the census block group level were then calculated.

\section{Methods}

Chloropleth maps displaying average NDVI values and crime densities provide a visual comparison of the spatial relationship between vegetation and crime. However, to quantitatively measure the directions and strength of correlation between crime and vegetation in Jefferson County, OLS regression was used. Applying the stepwise method, the OLS regression tested the explanatory power of vegetation rates using crime density 
as the dependent variable for this test, along with the other socioeconomic factors as the independent variables. A chloropleth map of the residuals from the best model and Moran’s I statistic were used to test for spatial dependence and clustering in the regression residuals. The Moran's I statistic ranges from -1 to 1 , with 0 indicating that all values are randomly dispersed (McGrew, Lembo, and Monroe 2014).

\section{RESULTS}

Examining the average NDVI map (Figure 2), the lower NDVI values are located in the north central region of Jefferson County, Kentucky. It is noteworthy that this region is the central business district. Around the outer edge of the county, particularly around the northwest and southern bounds, we find the highest NDVI values. The crime

density map (Figure 3), however, has high crime densities in the central business district. Most of the low crime density areas are within the eastern half of Jefferson County, with some low crime density dispersed along the southern edge as well. The crime density and NDVI maps display that there may be a negative relationship between the two. Most block groups containing low NDVI values have high densities of crime and vice versa.

There are some patterns that the other socioeconomic status maps all have in common. Generally, most of Jefferson County has high percentages of occupied houses (Figure 4). However, the area surrounding the central business district has the lowest concentrations of occupied houses. The poverty map (Figure 5), demonstrates an inverse pattern from the other socioeconomic maps. The highest concentrations of those living in poverty can be found in the north western and western portions of Jefferson County. Eastern Jefferson County contains mostly block groups with low levels of poverty. The 
highest levels of per capita income can be found in eastern Jefferson County (Figure 6). Western, and in particular, northwestern, Jefferson County has the lowest levels of per capita income. The areas within Jefferson County that have the lowest population densities surround most of the outermost edge of the county (Figure 6). The central business district, however, has many block groups containing high population densities. Population densities are also high in the central region of Jefferson County.

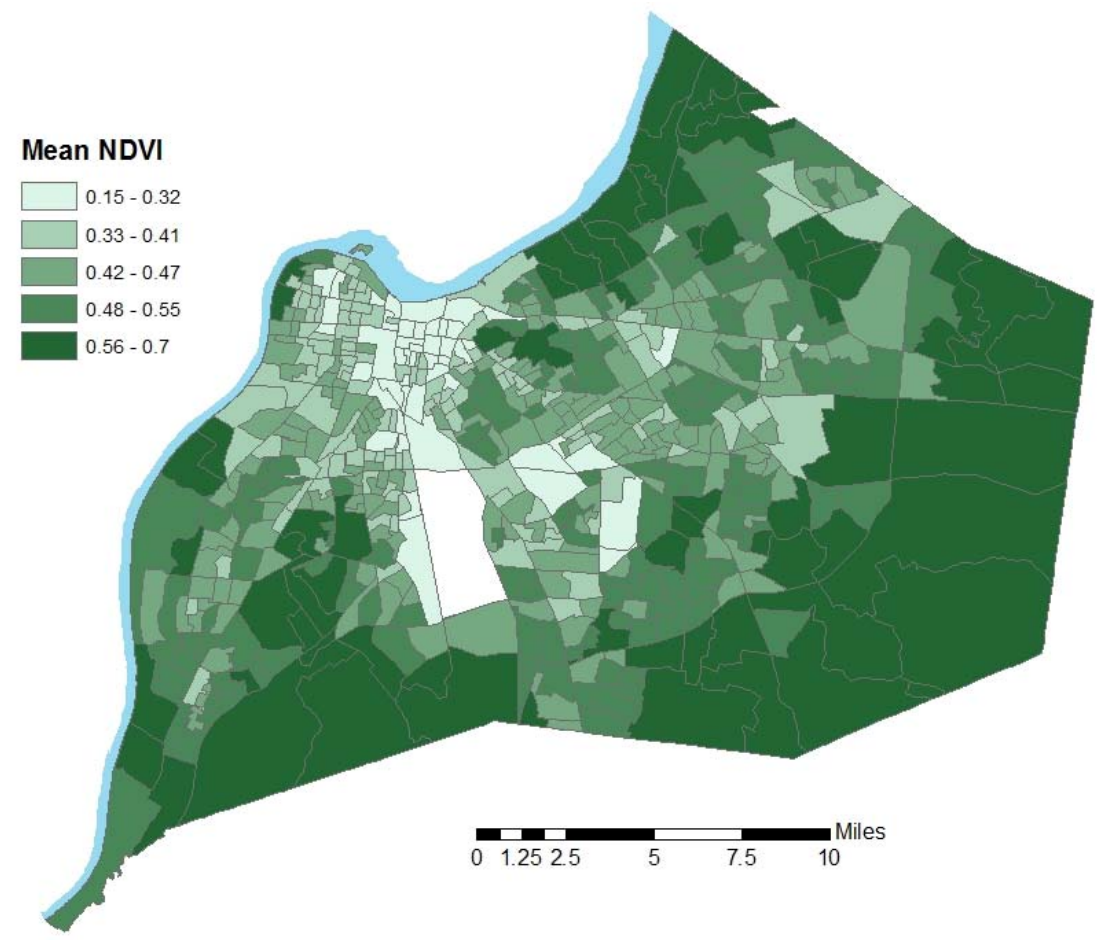

Figure 2. Average NDVI values 


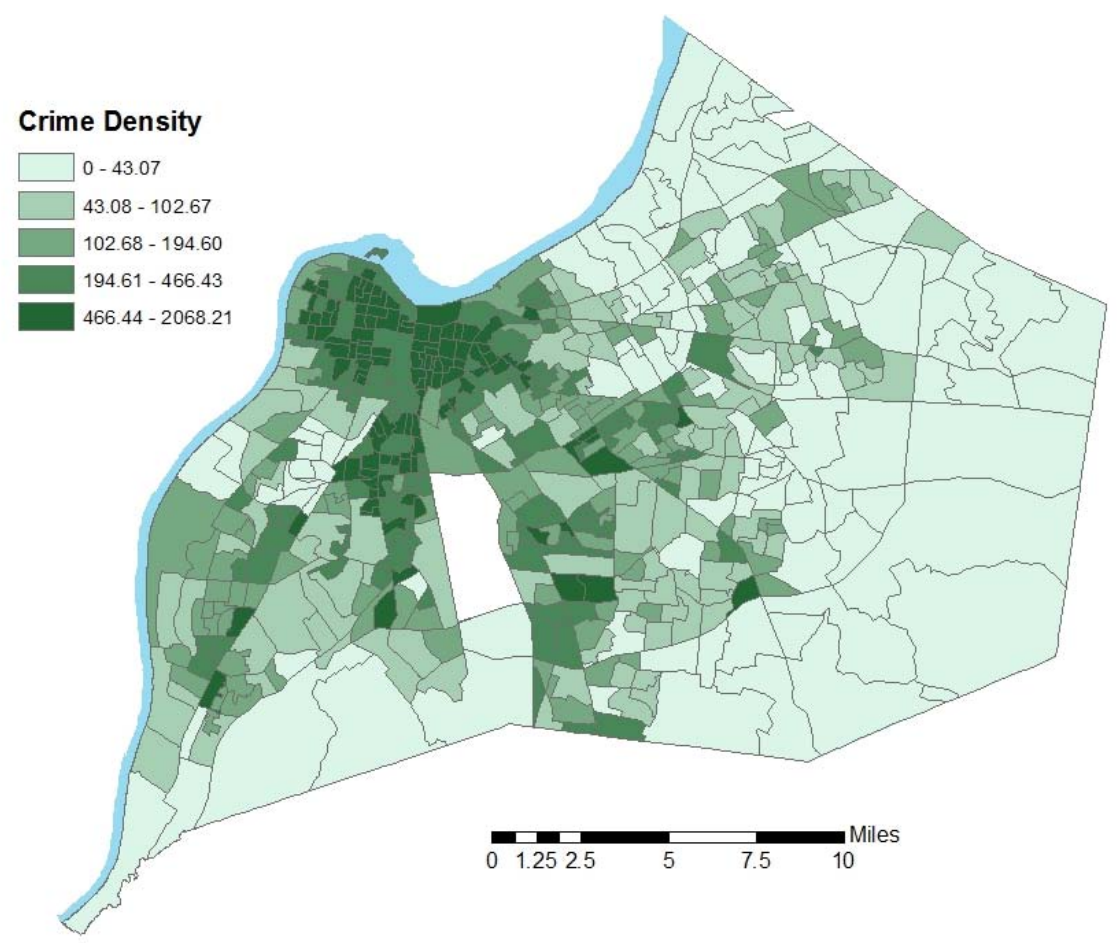

Figure 3. Number of crimes per sq. km.

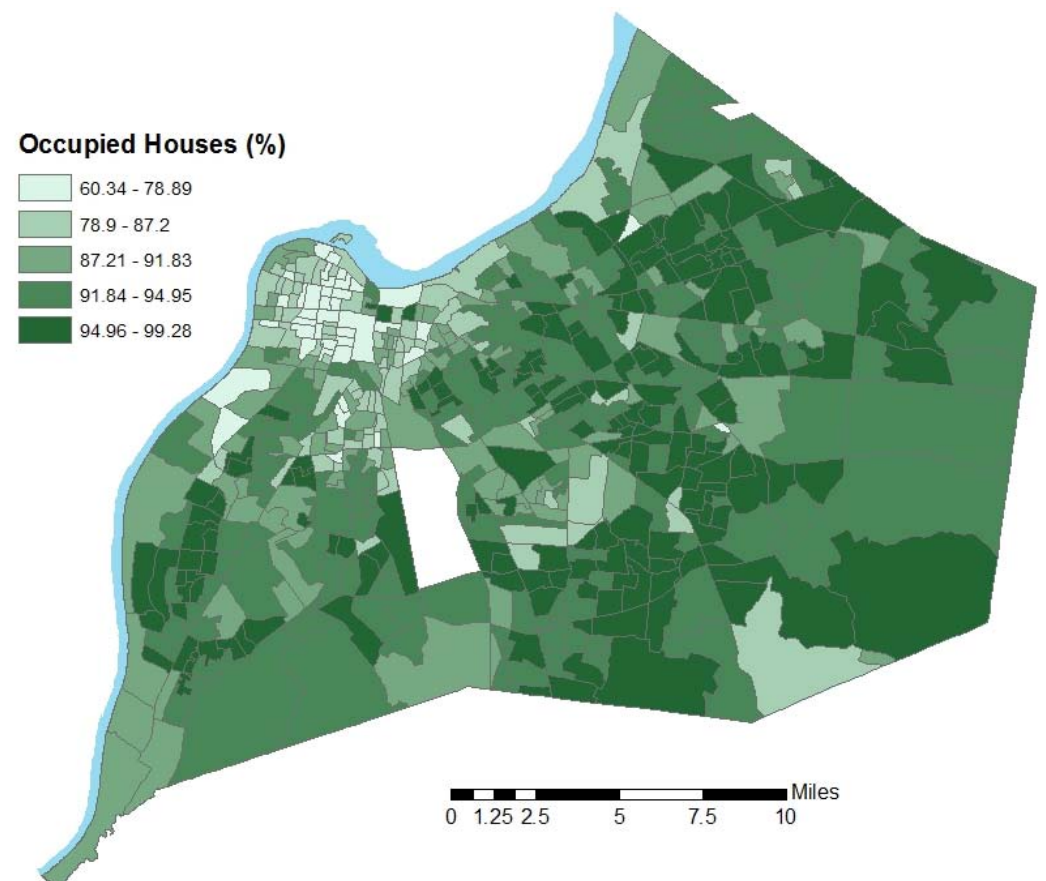

Figure 4. Percentage of occupied houses 


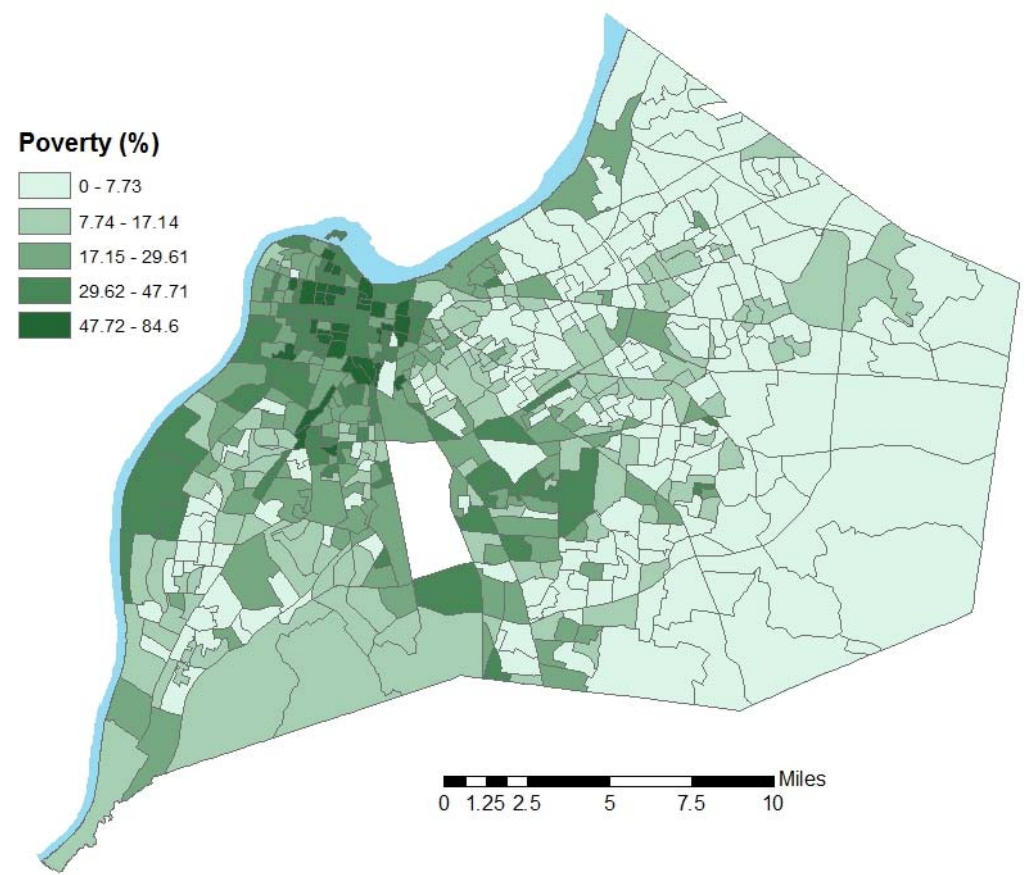

Figure 5. Percentage of people in each block group living in poverty.

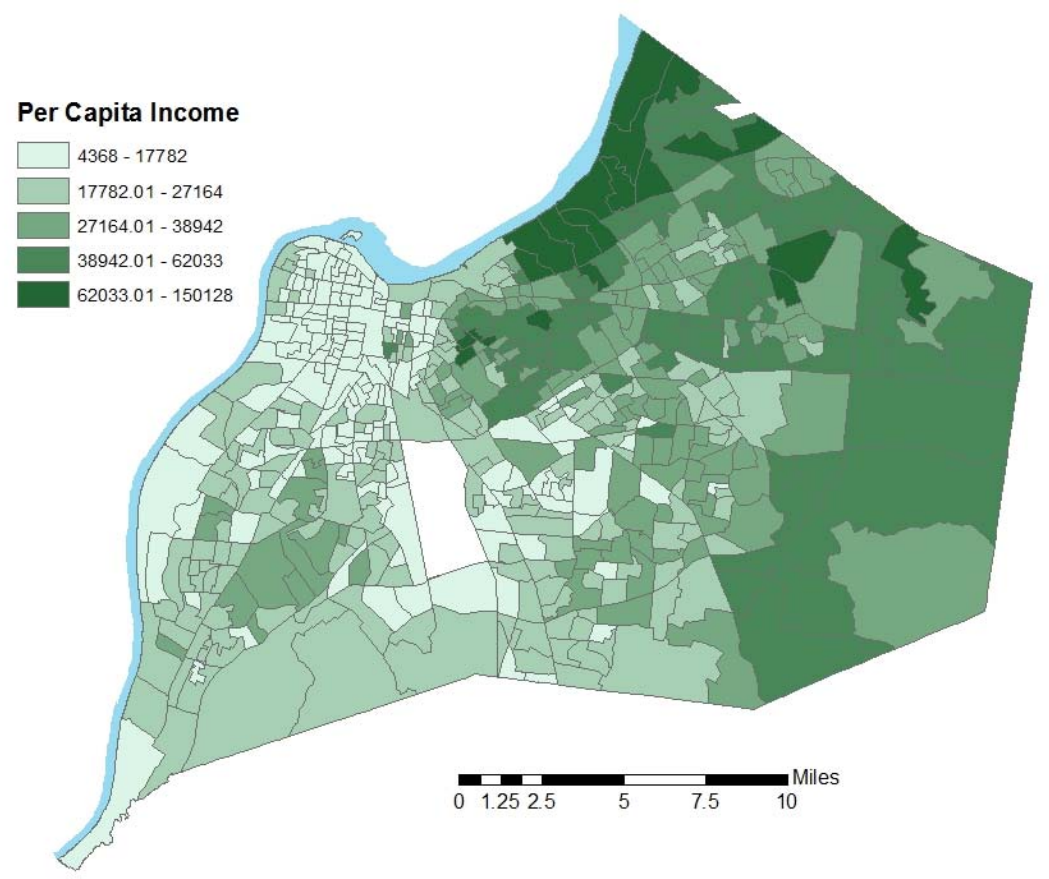

Figure 6. Per capita income. 




Figure 7. Population density

While several variables were not included in the final model as significant predictors of crime, their maps indicate that there are possible relationships between them and crime. In the map of educational attainment (Figure 8), we can see a divide between eastern and western Jefferson County. In the eastern portion of Jefferson County, almost all block groups have high levels of educational attainment. However, the western portion of Jefferson County has overall lower percentages of educational attainment. Levels of median age (Figure 9), however, are a bit more randomly dispersed. While median ages seem more random than other socioeconomic factors, northeastern and southeastern Jefferson County have the largest areas of block groups containing high median ages. Block groups containing the lowest median ages are dispersed throughout, and can be found in larger numbers in both central and northwest Jefferson County. The central business district and its surrounding area also have low percentages of those who own/mortgage houses (Figure 10). In general, the western half of Jefferson County has 
the lowest percentage of those who own/mortgage houses while the eastern half of Jefferson County has higher percentages of homeowners. However within the central region and spreading into parts of eastern Jefferson County, there is some variability among high and low percentages of homeowners.

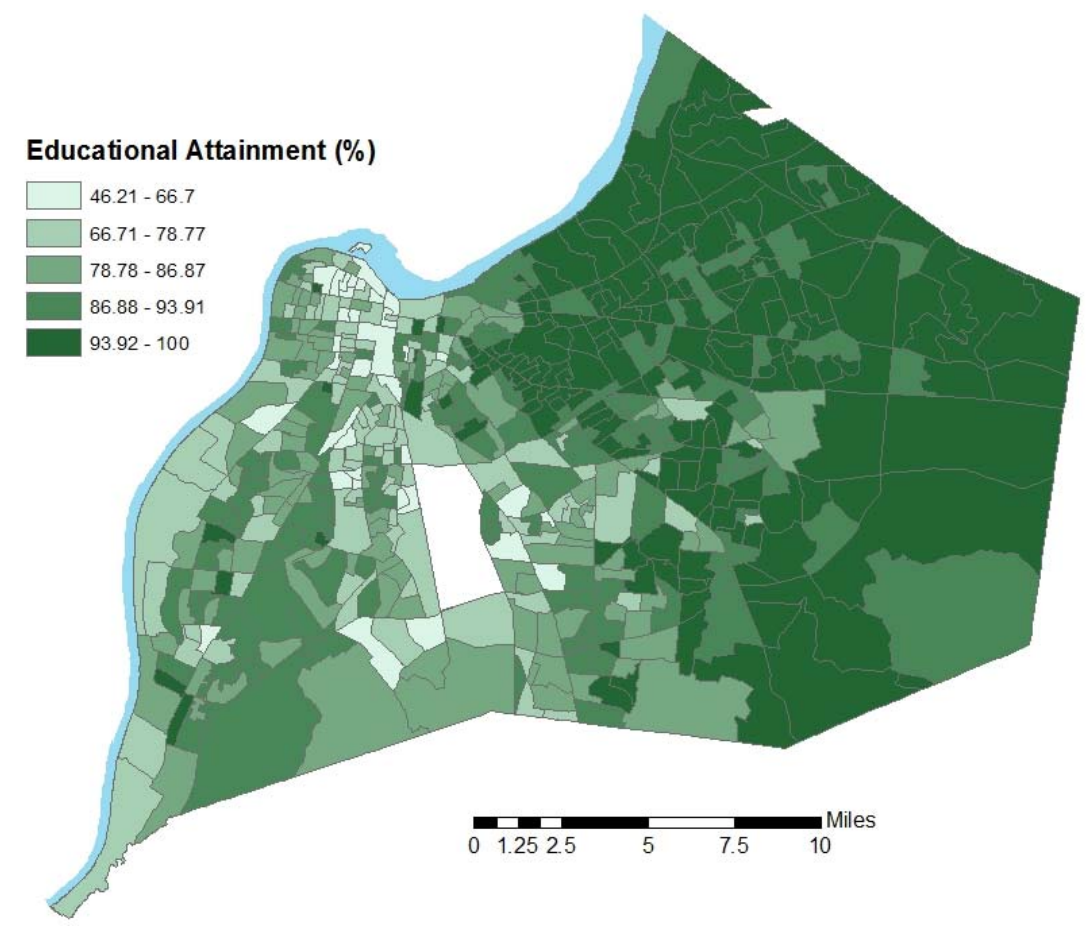

Figure 8. Percentage of Educational Attainment

Together, the maps demonstrate that there are distinct high and low socioeconomic status areas of Jefferson County. Western Jefferson County, and in particular, the northwestern portion, contain low socioeconomic status neighborhoods. Similarly, these are the areas with high densities of crime and low NDVI values. In contrast, eastern Jefferson County contains mainly high socioeconomic status areas, with low densities of crime and high NDVI values. Overall, we observe that higher average NDVI values occur in areas of higher socioeconomic status, while lower levels of NDVI values occur in areas of the county with lower socioeconomic status. 


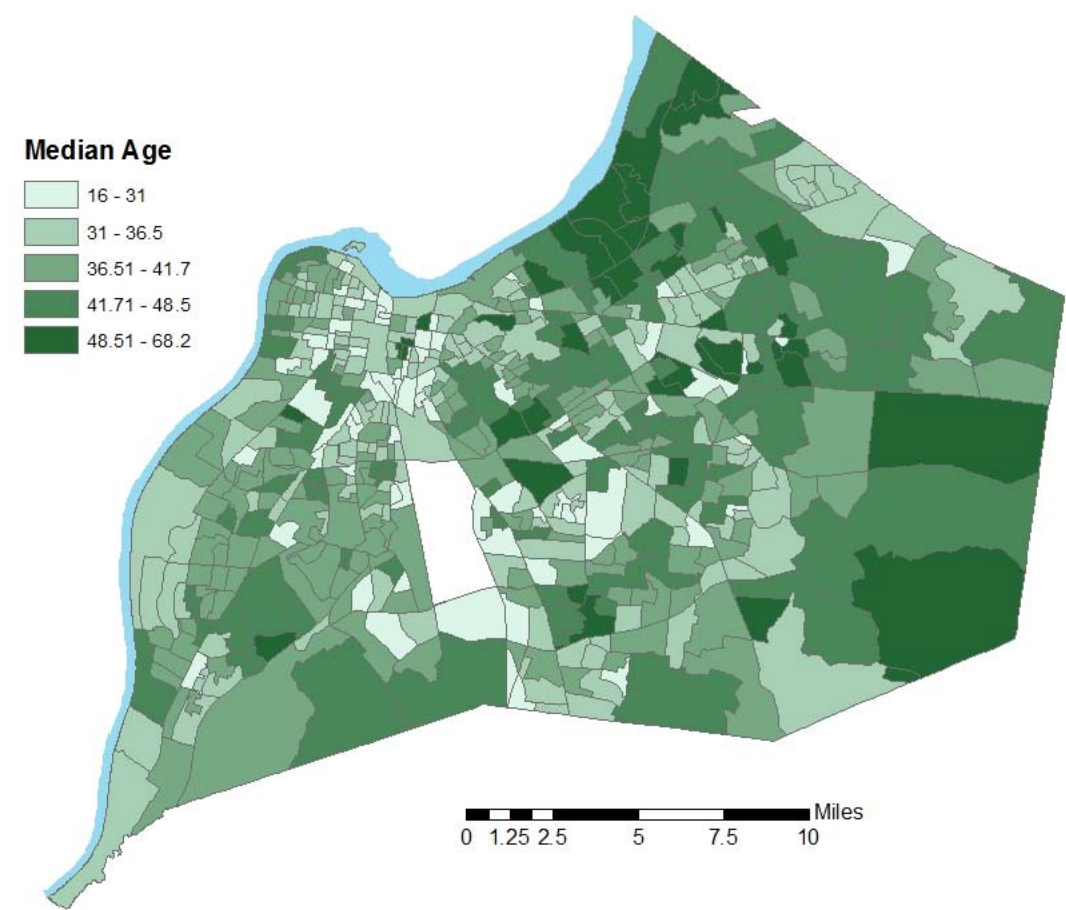

Figure 9. Median Age.



Figure 10. Percentage of houses that are owned/mortgaged. 
The correlations table gives similar results, with crime density significantly negatively correlated to mean NDVI values. Furthermore, mean NDVI values are significantly negatively correlated with population density and poverty. In addition to mean NDVI, crime is significantly negatively correlated with all other variables with the exception of population density and poverty. Apart from relationships between crime density and NDVI values, all of the variables in the matrix are significantly correlated to one another. While median age, owned/mortgaged houses, and educational attainment were not included in the final OLS model, they are significantly correlated with other variables, and therefore have an indirect relationship with crime.

\begin{tabular}{|c|c|c|c|c|c|c|c|c|}
\hline & $\begin{array}{c}\text { Owned/ } \\
\text { Mortgaged } \\
\text { Houses } \\
(\%)\end{array}$ & $\begin{array}{l}\text { Median } \\
\text { Age }\end{array}$ & $\begin{array}{c}\text { Occupied } \\
\text { Houses } \\
(\%)\end{array}$ & $\begin{array}{c}\text { Educational } \\
\text { Attainment } \\
(\%)\end{array}$ & $\begin{array}{l}\text { Mean } \\
\text { NDVI }\end{array}$ & $\begin{array}{l}\text { Poverty } \\
(\%)\end{array}$ & $\begin{array}{c}\text { Population } \\
\text { / sq. km. }\end{array}$ & $\begin{array}{c}\text { Crime } \\
\text { Density }\end{array}$ \\
\hline Median Age & $.619^{\star \star}$ & & & & & & & \\
\hline $\begin{array}{l}\text { Occupied } \\
\text { Houses (\%) }\end{array}$ & $.582^{\star \star}$ & $.357^{\star \star}$ & & & & & & \\
\hline $\begin{array}{l}\text { Educational } \\
\text { Attainment } \\
(\%)\end{array}$ & $.479^{\star \star}$ & $.340^{\star \star}$ & $.479^{\star \star}$ & & & & & \\
\hline Mean NDVI & $.636^{\star \star}$ & $.341^{\star \star}$ & $.400^{\star \star}$ & $.366^{\star \star}$ & & & & \\
\hline Poverty (\%) & $-.710^{\star *}$ & $-.468^{* *}$ & $-.603^{* *}$ & $-.644^{\star \star}$ & $-.521^{\star *}$ & & & \\
\hline $\begin{array}{l}\text { Population/ } \\
\text { sq. km. }\end{array}$ & $-.515^{\star \star}$ & $-.327^{\star \star}$ & $-.304^{\star \star}$ & $-.233^{\star \star}$ & $-.534^{\star \star}$ & $.411^{\star \star}$ & & \\
\hline Crime Density & $-.637^{\star \star}$ & $-.333^{\star *}$ & $-.566^{\star \star}$ & $-.412^{\star \star}$ & $-.628^{\star \star}$ & $.597^{\star \star}$ & $.666^{\star \star}$ & \\
\hline $\begin{array}{l}\text { Per Capita } \\
\text { Income }\end{array}$ & $.528^{\star \star}$ & $.512^{\star \star}$ & $.361^{\star *}$ & $.620^{\star *}$ & $.443^{\star \star}$ & $-.594^{\star \star}$ & $-.340^{\star \star}$ & $-.377^{\star \star}$ \\
\hline
\end{tabular}

**. Correlation is significant at the 0.01 level (2-tailed).

Table 1. Correlations matrix.

Examining the results of the OLS regression, Model 5 had the highest adjusted $\mathrm{R}$ square value at 0.651 and the lowest residual standard error. Model 5 is the result of a stepwise regression variable selection, as performed using SPSS v. 22 (IBM 2013). This final model included population density, occupied houses, mean NDVI, poverty, and per 
capita income as predictors of crime density. Assumptions of homoscedasticity, a linear relationship between independent and dependent variables, and no multicollinearity were tested and satisfied. Even after accounting for the other variables, this model shows that mean NDVI values serve as a statistically significant predictor of crime at the census block group level. Just as the chloropleth maps and correlation matrix indicated, when all other predictors are held constant, an increase in NDVI values is associated with a decrease in crime density. Furthermore, higher crime densities are associated with a lower percent of occupied houses and higher population densities, percent in poverty, and per capita income.

The residuals from the OLS model were mapped and can been seen in Figure 11. The Global Moran's I statistic was used to test the residuals of the OLS results. Model 5 has a Moran's I value of 0.24 , which is much lower than the other models. This indicates that the over- and under-predictions of Model 5 are more random than the other models. Since the statistic is positive and statistically significant, there is some degree of spatial clustering of the residuals. Wolfe and Mennis (2012) had similar, statistically significant Moran's I values of $0.19,0.20$, and 0.26 for their three models.

While employing different modeling approaches and testing procedures, many of the studies previously mentioned found similar results. Wolfe and Mennis (2012) implemented a similar methodology and discovered that crime and vegetation had a negative association with respect to robberies and burglaries, but not thefts. While Kuo and Sullivan (2001a) analyzed a much smaller area than this study, they also found that crime and vegetation had a negative relationship. Donovan and Prestemon (2012) found that large trees are associated with lower levels of crime; however, their studies indicate 
that not all vegetation affects crime the same. Findings of the study indicate that smaller trees on sidewalks and pathways are associated with higher levels of crime.

\begin{tabular}{|c|c|c|c|c|c|c|c|c|c|}
\hline \multirow{2}{*}{\multicolumn{2}{|c|}{ Model }} & \multicolumn{2}{|c|}{$\begin{array}{c}\text { Unstandardized } \\
\text { Coefficients }\end{array}$} & \multirow{2}{*}{$\begin{array}{c}\text { Standardized } \\
\text { Coefficients } \\
\text { Beta }\end{array}$} & \multirow{2}{*}{$\mathrm{t}$} & \multirow{2}{*}{ Sig. } & \multirow[b]{2}{*}{$\begin{array}{l}\text { Adjusted } \\
\text { R Square } \\
\end{array}$} & \multirow[b]{2}{*}{ Moran's } & \multirow[b]{2}{*}{ VIF } \\
\hline & & B & $\begin{array}{l}\text { Std. } \\
\text { Error }\end{array}$ & & & & & & \\
\hline \multirow[b]{2}{*}{1} & (Constant) & -65.863 & 18.286 & & -3.602 & 0.00 & & & \\
\hline & $\begin{array}{l}\text { Population/ } \\
\text { sq. km. }\end{array}$ & 0.194 & 0.009 & 0.666 & 21.333 & 0.00 & 0.442 & $0.58 * \star$ & 1.000 \\
\hline \multirow{3}{*}{2} & (Constant) & 1787.79 & 131.229 & & 13.623 & 0.00 & & & \\
\hline & $\begin{array}{l}\text { Population/ } \\
\text { sq. km. }\end{array}$ & 0.158 & 0.008 & 0.544 & 19.312 & 0.00 & & & 1.102 \\
\hline & $\begin{array}{l}\text { Occupied } \\
\text { Houses (\%) }\end{array}$ & -19.656 & 1.382 & -0.401 & 14.228 & 0.00 & 0.587 & 0.36 ** & 1.102 \\
\hline \multirow{4}{*}{3} & (Constant) & 1956.874 & 124.961 & & 15.66 & 0.00 & & & \\
\hline & $\begin{array}{l}\text { Population/ } \\
\text { sq. km. }\end{array}$ & 0.122 & 0.009 & 0.421 & 13.994 & 0.00 & & & 1.418 \\
\hline & $\begin{array}{l}\text { Occupied } \\
\text { Houses (\%) }\end{array}$ & -16.164 & 1.36 & -0.33 & 11.884 & 0.00 & & & 1.207 \\
\hline & Mean NDVI & -946.508 & 109.011 & -0.271 & -8.683 & 0.00 & 0.635 & $0.26^{\star \star}$ & 1.533 \\
\hline \multirow{5}{*}{4} & (Constant) & 1522.583 & 154.097 & & 9.881 & 0.00 & & & \\
\hline & $\begin{array}{l}\text { Population/ } \\
\text { sq. km. }\end{array}$ & 0.116 & 0.009 & 0.4 & 13.412 & 0.00 & & & 1.449 \\
\hline & $\begin{array}{l}\text { Occupied } \\
\text { Houses (\%) }\end{array}$ & -12.619 & 1.537 & -0.257 & -8.208 & 0.00 & & & 1.598 \\
\hline & Mean NDVI & -797.492 & 111.751 & -0.229 & -7.136 & 0.00 & & & 1.670 \\
\hline & Poverty (\%) & 3.157 & 0.677 & 0.158 & 4.662 & 0.00 & 0.648 & $0.25^{\star \star}$ & 1.880 \\
\hline \multirow{6}{*}{5} & (Constant) & 1477.107 & 154.59 & & 9.555 & 0.00 & & & \\
\hline & $\begin{array}{l}\text { Population/ } \\
\text { sq. km. }\end{array}$ & 0.118 & 0.009 & 0.404 & 13.585 & 0.00 & & & 1.454 \\
\hline & $\begin{array}{l}\text { Occupied } \\
\text { Houses (\%) }\end{array}$ & -12.533 & 1.531 & -0.256 & -8.184 & 0.00 & & & 1.599 \\
\hline & Mean NDVI & -840.333 & 112.675 & -0.241 & -7.458 & 0.00 & & & 1.712 \\
\hline & Poverty (\%) & 3.916 & 0.744 & 0.197 & 5.266 & 0.00 & & & 2.286 \\
\hline & $\begin{array}{l}\text { Per capita } \\
\text { income }\end{array}$ & 0.002 & 0.001 & 0.076 & 2.42 & 0.016 & 0.651 & $0.24^{\star \star}$ & 1.613 \\
\hline
\end{tabular}

a. Dependent Variable: Crime density **p $<0.05$

Table 2. OLS regression results. 


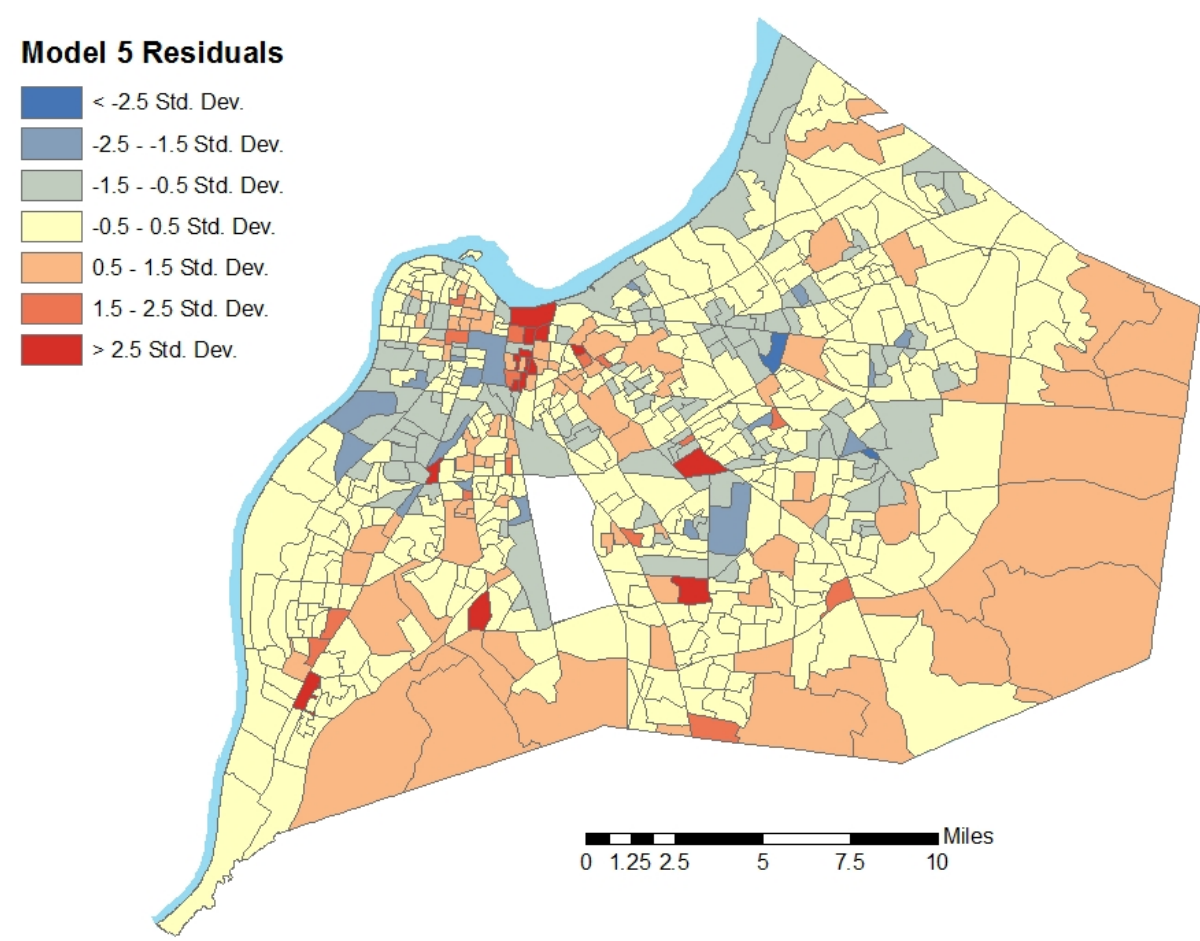

Figure 11. OLS Residuals

\section{CONCLUSION}

Through analyzing crime densities with NDVI values, this study has shown that there is a significant, negative relationship between the two in Jefferson County, Kentucky. Population density, percent occupied houses, mean NDVI values, percent in poverty, and per capita income are all statistically significant indicators of crime. Table 1 demonstrates that median age, educational attainment, and percent of owned/mortgaged houses have significant relationships between these variables and the other covariates; their multicollinearity with other variables prevents them from being statistically significant indicators of crime. However, their correlation with other variables demonstrates that they have subtle effects on crime. The model used in this study explains roughly 65 percent of the variation in crime densities at the block group level in Jefferson County. 
It is important to note that NDVI values measure the density of actively photosynthesizing vegetation. While an important measure of vegetation, this simplistic method of analyzing vegetation does not account for variability among different types of plants; NDVI values do not distinguish between different types or heights of vegetation. Since not all plants undergo photosynthesis throughout seasons at the same time, NDVI values are likely underrepresenting some vegetation in areas of Jefferson County while simultaneously exaggerating the amounts of vegetation in other areas.

Since some studies have indicated that types of vegetation are related to crime in different ways and in different degrees, future studies should take into account more complex factors of vegetation, such as degree of maintenance, classifications of vegetation, height and size of vegetation. This would allow for a better understanding of the specific aspects of vegetation that are most related to crime. It is also likely that different kinds of crimes have varying relationships with vegetation, as shown by Wolfe and Mennis (2012). It could be beneficial for future studies to analyze the way different kinds of crimes relate to vegetation. Furthermore, it is likely that not all crime is patrolled equally. Lower socioeconomic status neighborhoods, in particular, may have different patrolling and enforcement rates than higher socioeconomic status neighborhoods, causing over- and under-reporting of crimes in certain areas. Expanding this study using these other approaches may give us a deeper understanding of the way humans and our environment react with respect to committing crimes and guide future management efforts.

This study adds to the broad body of evidence suggesting vegetation and crime are inversely related. While this relationship may not be one that is causal, this study 
highlights that there is certainly a robust linkage between crime and vegetation when accounting for other social and demographic variables. Studies such as this can increase our understanding of the way humans and our environment interact, and can be beneficial for implementing policy within Jefferson County and throughout other areas. Within Jefferson County, there are clear inequalities. Eastern Jefferson County is composed of high socioeconomic status neighborhoods containing large levels of vegetation, while western, especially north western, Jefferson County is composed of low socioeconomic status neighborhoods with low levels of vegetation. This study should be used to examine these disparities, and give both the general public and policy makers some guidance for making Jefferson County a more equal, safe, and green community. 


\section{REFERENCES}

Cohen, L. E. and M. Felson. 1979. Social change and crime rate trends: a routine activity approach. American Sociological Review 44: 588-608.

Donovan, G and J. P. Prestemon. 2010. The Effect of Trees on Crime in Portland, Oregon. Environment and Behavior 44 (1): 3-30.

ESRI. 2011. ArcGIS Desktop: Version 10.2.2. Redlands, CA: Environmental Systems Research Institute.

Fisher, B. S. and J. L. Nasar. 1992. Fear of Crime in Relation to Three Exterior Site Features: Prospect, Refuge, and Escape. Environment and Behavior 133 (24): 3565.

IBM Corp. Released 2013. IBM SPSS Statistics for Windows, Version 22.0. Armonk, NY: IBM Corp.

Kelling, G. L., and J. O. Wilson. 1982. Broken Windows. The Atlantic Monthly 249 (3): 29-38.

Kuo, F. E., and W.C. Sullivan. 2001a. Environment and Crime in the Inner City: Does Vegetation Reduce Crime? Environment and Behavior 33 (3): 343-367.

Kuo, F.E., and W. C. Sullivan. 2001b. Aggression And Violence in the Inner City: Effects of Environment via Mental Fatigue. Environment and Behavior 33 (4): 543-571.

Louisville/Jefferson County Information Consortium (LOJIC). MetroBlockGroup2010. Louisville, KY: LOJIC, 2011.

Louisville Metro Government. 2014. Tree Advisory Commission. Available at http://www.louisvilleky.gov/government/sustainability/tree-advisory-commission (last accessed 14 October 2014). 
Maguire, M., R. Morgan, and R. Reiner. 2002. The Oxford Handbook of Criminology. New York: Oxford University Press.

McGrew Jr., J. C., J. Lembo Jr., and C. Monroe. 2014. An Introduction to Statistical Problem Solving in Geography. Long Grove, Illinois: Waveland Press, Inc.

Michael, S. E., B. Hull, and D. L. Zahm. 2011. Environmental Factors Influencing Auto Burglary: A Case Study. Environment and Behavior 33 (3): 368-388.

NASA Earth Observatory. 2000. Measuring Vegetation (NDVI \& EVI). Available at http://earthobservatory.nasa.gov/Features/MeasuringVegetation// (last accessed 30 October 2014).

Jeffrey, R.C. 1971. Crime prevention through environmental design. Beverly Hills, CA: Sage.

Jensen, J. R. 2005. Introductory Digital Image Processing, $3^{\text {rd }}$ ed. Upper Saddle River, NJ: Prentice-Hall.

Talbot, J., and R. Kaplan. 1984. Needs and fears: The response to trees and nature in the inner city. Journal of Arboriculture 10 (8): 222-228.

Troy, A., J. M. Grove, and J. O’Neil-Dunne. 2012. The relationship between tree canopy and crime rates across an urban-rural gradient in the greater Baltimore region. Landscape and Urban Planning 106 (3): 262-270.

U.S. Census Bureau. 2010a. State and County QuickFacts: Jefferson County, Kentucky. Available at http://quickfacts.census.gov/qfd/states/21/21111.html (last accessed 21 October 2014).

U.S. Census Bureau. 2010b. 2010 Census Urban and Rural Classification and Urban Area Criteria. Available at http://www.census.gov/geo/reference/ua/urban-rural2010.html (last accessed 21 October 2014). 
Wolfe, M.K., J. Mennis. 2012. Does vegetation encourage or suppress crime? Evidence from Philadelphia, PA. Landscape and Urban Planning 108 (2-4): 112-122.

Wortley, R. and L. G. Mazerolle. 2008. Environmental criminology and crime analysis. Devon, UK: Willian Pub. 